\title{
Applications of 5-aminolevulinic acid on the physiological and biochemical characteristics of strawberry fruit during postharvest cold storage
}

\author{
5-aminolevulínico ácido sobre as características \\ fisiológicas e bioquímicas de morango
}

\author{
Yi Li ${ }^{\text {III }}$ Zhiqiang Li $^{\text {III }}$ \\ Liangju Wang ${ }^{I^{*}}$
}

ABSTRACT

The compound 5-aminolevulinic acid (ALA) is a key precursor in the biosynthesis of porphyrins, such as chlorophyll, heme and phytochromobilin, and has multiple physiological effects on plants. Varying concentrations of ALA $\left(50 \mathrm{mg} \mathrm{L}^{-1}, 100 \mathrm{mg} \mathrm{L}^{-1}\right.$, and $\left.150 \mathrm{mg} \mathrm{L}^{-1}\right)$ and water (control) were applied to white stage 'Sweet Charlie' strawberry fruit. All ALA treatments delayed senescence and improved the qualities of strawberries fruit during storage. Among the treatments, $150 \mathrm{mg} \mathrm{L}^{-1}$ ALA was the most effective dosage concentration. Exogenously applied ALA significantly reduced the decay index, respiration rate, $\mathrm{O}_{2}^{-}$production rate $\left(\mathrm{O}_{2}^{-}\right), \mathrm{H}_{2} \mathrm{O}_{2}$ and malondialdehyde (MDA) content, increased superoxide dismutase (SOD), ascorbate peroxidase activities (APX), total soluble solids (TSS) content, titratable acidity (TA) and anthocyanin content during the initial stage of storage. These results supported the pre harvest application of ALA as a beneficial strategy for the prevention of postharvest decay of strawberry fruit.

Key words: antioxidant enzyme, Fragaria $\times$ ananassa, storage, preharvest, quality.

\section{RESUMO}

$O$ composto de ácido 5-aminolevulínico (ALA) é um precursor chave na biossintese de porfirinas, tais como clorofilae porfirinas, e verificou-se induzir elevações temporárias na taxa de fotossintese e APX. Além disso, ele tem vários efeitos fisiológicos sobre os vegetais. Após o tratamento, Ala (50mg $\mathrm{L}^{-1}$, $100 \mathrm{mg} \mathrm{L}^{-1}$ e $150 \mathrm{mg} \mathrm{L}^{-1}$ ) ou água (controlo) foi aplicado a frutos maduros branco "Sweet Charlie" de morango. As atividades indice de decadência, taxa de respiração, superóxido dismutase e ascorbato peroxidase, conteúdo de sólidos solúveis, acidez titulável, teor de antocianinas, taxa de produção de $\mathrm{O2}^{-}$, e conteúdo malondialdehyde foi avaliada nos frutos ALA-tratados e morango controle durante a armazenagem a $4{ }^{\circ} \mathrm{C}$. Os resultados mostraram que a aplicação exógena de ALA retarda a senescência e melhorou o valor nutricional das frutas de morango durante o armazenamento.

Palavras-chave: Fragaria $\times$ ananassa, frutos de morango, ácido 5-aminolevulínico, armazenamento, enzimas antioxidantes.

\section{INTRODUCTION}

Strawberry (Fragaria $\times$ ananassa D.) is a dietary source of ascorbic acid, flavonoids, and anthocyanins. Consumers are attracted to the aroma and bright red color of strawberry fruits; however, strawberry fruit is susceptible to mechanical injury, water loss, and decay. Therefore, many strategies have been developed to keep strawberries fresh for a longer storage period while preserving the fruit's desired texture and flavor. For example, strategies have included UV-C and high-intensity pulsed electric fields, high carbon dioxide, nitric oxide, 1-methylcyclopropene, low temperature treatments, etc. (ZHU et al., 2010). These methods delay senescence by reducing the levels of reactive oxygen species (ROS), inhibiting respiration (WANG et al., 2014), and increasing the production of oxygen

ICollege of Horticulture, Nanjing Agricultural University, Nanjing, 210095, Jiangsu, China. E-mail: wlj@njau.edu.cn. *Corresponding author. IInstitute of Vegetables and Flowers, Shandong Academy of Agricultural Sciences/Shandong Key Laboratory of Greenhouse Vegetable Biology/Shandong Branch of National Vegetable Improvement Center, Jina, China.

IIIJiangsu Academy of Agricultural sciences, Nanjing, China. 
radical scavengers such as SOD, peroxidases (POD) and APX (ZHU et al., 2010).

ALA is a key precursor in the biosynthesis of heme, which is a prosthetic group of hemoproteins, including cytoglobins, cytochrome, POD, SOD, and catalase (CAT) (HOODA et al., 2015). The $C^{14}$ labelled-ALA was incorporated into the POD molecule in peas treated over a $16 \mathrm{~h}$ incubation period (NISHIHARA et al., 2003). Exogenously applied ALA increases the activities of enzymatic antioxidants, such as SOD, POD and CAT, under water stress (KOSAR et al., 2015). ALA also provides significant protection against cold stress in germinating seeds, and increases low-light irradiation tolerance of water melon seedlings (FU et al., 2014).

Exogenously applied ALA showed to improve fruits qualitiy. ALA increases the percentage of dry matter and sugar and citric acid contents of strawberry fruit (IWAI et al., 2004). Exogenous ALA promoted fruit coloration of apple when sprayed 20 days before harvest (WANG et al., 2004). However, until now, the effect of ALA on postharvest strawberry physiology has not been reported. Based on these arguments, we are proceeding with the working hypothesis that preharvest applications of ALA could delay senescence and improve the qualities of strawberry fruit. This study assesses the effect of ALA on the physiological index of strawberry fruit during storage, and provides evidence that low concentrations of exogenous ALA can delay senescence and improve the fruit qualities of strawberry fruit during cold storage.

\section{MATERIALS AND METHODS}

\section{Fruit and treatments}

Strawberries (Fragaria $\times$ ananassa

Duch.cv.Sweet Charlie) were grown in unheated greenhouses in a commercial farm located in Nanjing (Jiangsu, China). White stage strawberry fruit was sprayed with water (control) or ALAs at different concentrations $\left(50 \mathrm{mg} \mathrm{L}^{-1}, 100 \mathrm{mg} \mathrm{L}^{-1}\right.$, or $150 \mathrm{mg} \mathrm{L}^{-1}$ ) according to the report of MEMON et al. (2009), harvested when the $1 / 3$ fruit turned red, and transported to storage rooms at Nanjing Agricultural University. Damaged, shriveled, or unripe fruit was discarded. Control and ALA-treated fruit was randomly divided into five groups based on size and color and stored in polypropylene boxes $(80 \mathrm{~cm} \times 60 \mathrm{~cm} \times 30 \mathrm{~cm} ; 80-90 \%$ relative humidity) for $0,2,4,6$, or 8 days at $4^{\circ} \mathrm{C}$. Each box, which contained 30 fruit, was considered an experimental unit. Fruit was frozen in liquid nitrogen and stored at $-80^{\circ} \mathrm{C}$ for physiological and biochemical analyses.

Decay analysis

Fruit decay was visually evaluated in 30 fruit from each treatment. Based on the decay level, the fruit was classified as $0=$ normal (no decay on fruit surface); $1=$ trace ( $5 \%$ of fruit surface was decayed); $2=$ slight $(5-20 \%$ of fruit surface was decayed $) ; 3=$ moderate $(20-50 \%$ of fruit surface was decayed); or $4=$ severe $(>50 \%$ of fruit surface was decayed $)$.

Decay index $=\frac{\text { A decay index was calculated by }}{1 \times \mathrm{N} 1+2 \times \mathrm{N} 2+3 \times \mathrm{N} 3+4 \times \mathrm{N} 4} \times 100$

Where $\mathrm{N}$ represents the total number of fruit and N1, N2, N3, and N4 represent the number of fruit with different decay levels (i.e., 1- 4).

Measurement of respiration rate

$\mathrm{CO}_{2}$ analyses were performed using an infrared carbon dioxide analyzer (Telaire-700, Spectrum TM Technologies Inc, City, State, USA). Thirty strawberry fruits were enclosed in a 9.46-L glass container. The $\mathrm{CO}_{2}$ concentrations in the container were determined after $30 \mathrm{~min}$. Respiration rate was expressed as $\mathrm{nM} \mathrm{CO}_{2} \mathrm{~g}^{-1} \mathrm{~min}^{-1}$.

Detecting $\mathrm{O}_{2}^{-}$production rate, $\mathrm{H}_{2} \mathrm{O}_{2}$ concentration, and MDA content

$\mathrm{O}_{2}^{-}$production rate $\left(\mathrm{O}_{2}^{-}\right)$was determined at $530 \mathrm{~nm}$ by the method reported by WANG et al. (2000). $\mathrm{O}_{2}^{-}$production rate was expressed as nmol $\mathrm{g}^{-1} \mathrm{~min}^{-1}$. Concentration of hydrogen peroxide $\left(\mathrm{H}_{2} \mathrm{O}_{2}\right)$ was analyzed by the method reported by Wang et al. (2000). Concentration of $\mathrm{H}_{2} \mathrm{O}_{2}$ was expressed as $\mu \mathrm{mol}$ $\mathrm{g}^{-1}$. Anthocyanins and other compounds in strawberry fruit absorb at 532nm. To increase the accuracy of the 2-thiobarbituric acid-malondialdehyde (TBA-MDA) method, the absorbance measurement at $532 \mathrm{~nm}$ of a sample containing strawberry fruit but no TBA was subtracted from the absorbance measurement at $532 \mathrm{~nm}$ of an identical sample containing TBA. The MDA content was determined according to the method reported by HODGES et al. (1999). Concentration of MDA was expressed as nmol $\mathrm{g}^{-1}$.

Detection of SOD and APX activity

Strawberry fruit $(2 \mathrm{~g})$ was ground in a cold mortar and pestle until no fibrous residue could be seen, homogenized in $10 \mathrm{ml}$ of $50 \mathrm{mM}$ sodium phosphate buffer ( $\mathrm{pH} 7.8$ for SOD extraction or $\mathrm{pH}$ 7.0 for APX extraction) containing 1\% polyvinylpolypyrrolidone and 1mM EDTA, and centrifuged at 
$12,000 \mathrm{x}$ g for $15 \mathrm{~min}$ at $4^{\circ} \mathrm{C}$. Supernatant, containing crude enzymes, was used to determine SOD and APX activities.

The SOD activity was measured by the method reported by BEYER \& FRIDOVICH (1987). One unit of SOD activity was defined as the amount of enzyme that produced $50 \%$ inhibition of nitroblue tetrazolium reduction under the assay conditions. The assay was performed at $20^{\circ} \mathrm{C}$. Activity of SOD was expressed as $\mathrm{U} \mathrm{g}^{-1}$.

APX activity was determined by assessing the rate of ascorbate oxidation at $290 \mathrm{~nm}$ for $3 \mathrm{~min}$. The assay was performed at $20^{\circ} \mathrm{C}$. APX activity was expressed as A290 g $\mathrm{g}^{-1} \mathrm{~min}^{-1}$.

Determination of TSS, TA, and anthocyanin content

In this experiment, 10 fruit from each experimental unit was wrapped in cheese cloth and hand-squeezed. The resulting strawberry fruit juice was analyzed for TSS and TA (WANG et al., 2002). Total anthocyanin content of strawberry fruit extract was determined using the method reported by MEYERS et al. (2003). Total anthocyanin concentrations were expressed as cyanidin 3 -glucoside per fruit weight. The anthocyanin concentration was expressed as $\mathrm{mg} 100 \mathrm{~g}^{-1}$.

Statistical analyses

Three independent replicates $(n=3)$ were prepared per control and ALA treatment. Data were analyzed by one-way ANOVA using SPSS 16.0 software. $P<0.05$ as significant according to Tukey's multiple range test.

\section{RESULTS}

Efficacy of ALA on the decay index of strawberry fruit Strawberry fruit began to decay after 2 days of storage. Pre-harvest application of ALA significantly reduced $(P<0.05$; Figure 1A) the incidence of mold decay in strawberry fruit from 2 days storage at $4^{\circ} \mathrm{C}$. Decay index of the $150 \mathrm{mg} \mathrm{L}^{-1}$ ALA treatments (3.5\%) were 50\% lower than the control $(7.5 \%)$ at 2 days storage at $4{ }^{\circ} \mathrm{C}$. The decay index of the $150 \mathrm{mg} \mathrm{L}^{-1}$ ALA treatments $(18.5 \%)$ was $44 \%$ lower than the control $(33.7 \%)$ at day 8 .

\section{Detecting respiration rate}

The respiration rate of strawberry fruit was measured during 8 days of storage (Figure 1B). ALA treatments could inhibit the respiration of strawberry fruit. Compared to the control fruit, the ALA-treated fruit had lower respiration rate throughout storage.
From the 6 day of storage, the respiration rate was significantly reduced in ALA-treated fruit than control $(P<0.05)$. The respiration rate of $100 \mathrm{mg} \mathrm{L}^{-1}$ treated ALA $\left(12.82 \mathrm{nM} \mathrm{CO}_{2} \mathrm{~g}^{-1} \mathrm{~min}^{-1}\right.$ and $\left.17.55 \mathrm{nM} \mathrm{CO}_{2} \mathrm{~g}^{-1} \mathrm{~min}^{-1}\right)$ was $23.4 \%$ and $45.7 \%$ lower than that of control fruit at 6 day and 8 day of storage, respectively.

Determination of $\mathrm{O}_{2}^{-}$production, $\mathrm{H}_{2} \mathrm{O}_{2}$ content and MDA content

The $\mathrm{O}_{2}^{-}$production rate of strawberry fruit was $0.052 \mathrm{nmol} \mathrm{g}^{-1} \mathrm{~min}^{-1}$ at harvest. The control strawberry fruit had the highest $\mathrm{O}_{2}$ - production rate $\left(0.223 \mathrm{nmol} \mathrm{g}^{-1} \mathrm{~min}^{-1}\right)$ after 6 days of storage. The $\mathrm{O}_{2}^{-}$production rate of strawberry fruit in all ALA treatments increased throughout storage. The $\mathrm{O}_{2}^{-}$ production rate of ALA-treated fruit was lower than that of control fruit during storage (Figure 1C); however, the difference was not significant between treatment and control.

The $\mathrm{H}_{2} \mathrm{O}_{2}$ content exhibited a similar trend to the $\mathrm{O}_{2}^{-}$production rate in ALA-treated fruit. At harvest, $\mathrm{H}_{2} \mathrm{O}_{2}$ content was higher in ALAtreated fruit than in control fruit. $\mathrm{H}_{2} \mathrm{O}_{2}$ content in control fruit was higher than ALA-treated fruit after 4 days of storage, and it was $23.13 \%$ higher than the $150 \mathrm{mg} \mathrm{L}^{-1}$. The ALA-treated fruit after 8 days of storage, the difference was significant $(P<0.05)$ (Figure 1D).

Lipid peroxidation was assessed by measuring MDA content (Figure 1E). MDA content in all strawberry fruit increased during storage. Compared to the ALA-treated fruit, the control fruit had higher MDA content. MDA content in fruit treated with ALA was significantly lower $(P<0.05)$ than that in control fruit after 4 days of storage. At the end of storage, MDA content in ALA-treated fruit $\left(50 \mathrm{mg} \mathrm{L}^{-1}\right.$ (8.4nmol g-1), 100 $\mathrm{mg} \mathrm{L}^{-1}\left(7.9 \mathrm{nmol} \mathrm{g}{ }^{-1}\right)$, or $150 \mathrm{mg} \mathrm{L}^{-1}$ $\operatorname{ALA}\left(8.2 \mathrm{nmol} \mathrm{g}^{-1}\right)$ was $15.4 \%, 21.7 \%$, and $17.1 \%$ lower than that in control fruit $\left(9.9 \mathrm{nmol} \mathrm{g}^{-1}\right)$, respectively.

\section{Quantification of SOD and APX activity}

SOD activity in strawberry fruit reached maximum levels on day 2 of storage and subsequently decreased. SOD activity in ALA-treated fruit was higher than that in control fruit after 2 days of storage. SOD activity in the $150 \mathrm{mg} \mathrm{L}^{-1}$ ALA-treated fruit (104.67 $\left.\mathrm{U} \mathrm{g}^{-1} \mathrm{FW}\right)$ was significantly higher than in control fruit $\left(100.1 \mathrm{U} \mathrm{g} \mathrm{g}^{-1} \mathrm{FW}\right)$ after 6 days of storage $(P<0.05$; Figure $1 \mathrm{~F})$.

APX activity increased in all fruit during storage. APX activity of control fruit was $25 \%$ lower than those in $150 \mathrm{mg} / \mathrm{L}$ ALA-treated fruit. APX activity of ALA-treated fruit was consistently higher 

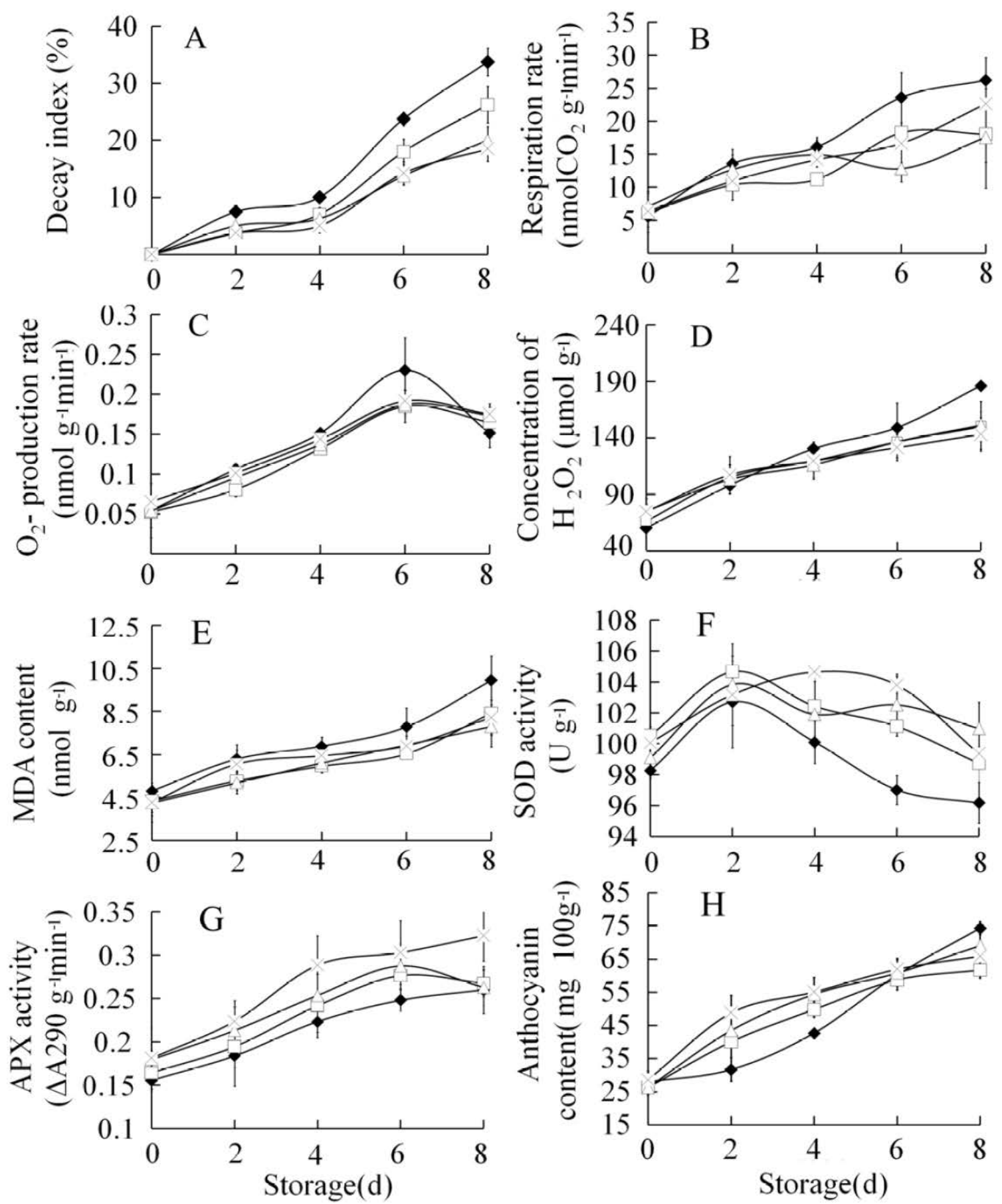

-Control $\square 50 \mathrm{mg} / \mathrm{L} \quad 100 \mathrm{mg} / \mathrm{L} \quad 150 \mathrm{mg} / \mathrm{L}$

Figure 1 - Analysis of ALA on eight physiological indexes of strawberry fruit. Effect of ALA on decay index (A), respiration rate (B), $\mathrm{O}_{2}$ - production rate $(\mathrm{C})$, concentration of $\mathrm{H}_{2} \mathrm{O}_{2}(\mathrm{D})$, MDA content (E), SOD activity (F), APX activity (G) and anthocyanin content $(\mathrm{H})$ of strawberry fruits during storage after harvest at $2,4,6$, and 8 day in $4 \pm 1{ }^{\circ} \mathrm{C}$. Vertical bars represent $\mathrm{SD}(\mathrm{n}=3$ ). 
than that of control fruit throughout storage; however, there were no significant differences in enzymatic activity among ALA treatments (Figure 1G).

Effect of ALA on fruit TSS, TA, and anthocyanin content

The TSS (Figure 2A) and TA (Figure 2B) were assessed in strawberry fruit during storage at $4^{\circ} \mathrm{C}$. The TSS and TA were higher in ALA-treated fruit than in control fruit. A slight increase in TSS was obtained in all ALA treatments from day 2 to day 6 , followed by a sharp reduction in TSS from day 6 to day 8. TSS was significantly higher in ALAtreated fruit than in control at the end of storage period $(P<0.05)$. TA decreased from day 2 of storage. There were no significant differences among the ALA treatments after day 2 of storage; however, ALAtreated fruit had higher TA than control fruit.

At harvest, strawberry fruit had approximately $28 \mathrm{mg}^{100 \mathrm{~g}^{-1}}$ of anthocyanin (Figure $1 \mathrm{H})$. Anthocyanin content was significantly affected by ALA treatment. The highest anthocyanin content (48.8mg $100 \mathrm{~g}^{-1}$ ) was obtained with $150 \mathrm{mg} \mathrm{L}^{-1}$ ALA, followed by $100 \mathrm{mg} \mathrm{L}^{-1}$ and $50 \mathrm{mg} \mathrm{L}^{-1}$ ALA $(43.5 \mathrm{mg}$ $100 \mathrm{~g}^{-1}$ and $40.1 \mathrm{mg}^{100 \mathrm{~g}^{-1}}$, respectively). After 2 days of storage, the anthocyanin content of the $150 \mathrm{mg} \mathrm{L}^{-1}$, $100 \mathrm{mg} \mathrm{L}^{-1}$, and $50 \mathrm{mg} \mathrm{L}^{-1}$ ALA treatments were $26.5 \%$, $37.1 \%$, and $53.9 \%$ higher $(P<0.05)$, respectively, than the control. At 6 days of storage, there were no significant differences between ALA-treated fruit and control fruit. At 8 days of storage, control fruit had significantly higher anthocyanin content $(20.39 \%$ higher) than 50mg L-1 ALA-treated fruit $(P<0.05)$.

\section{DISCUSSION}

Strawberry fruit is highly perishable and susceptible to physiological deterioration and fungal decay. Gray mold, wide spread in the environment, is the most serious disease causing strawberry fruit rot (ZAVALA et al., 2004). In this study, pre-harvest applications of ALA resulted in a decrease of the decay index of strawberry fruit during storage, confirming the fact that ALA can suppress microfungi development (LUKSIENE et al., 2007). So, probably this is the first report that ALA reduces the decay index of fruit, and our findings have shown that pre harvest applications of ALA are a viable good strategy for the prevention of postharvest decay in strawberry fruit.

Reducing initial respiration rate is critical for extending shelf-life (LEE et al., 2003). Specifically, lower respiration rate is beneficial for decreasing ROS levels during storage. Previous studies have reported that ALA in low concentrations decreases respiratory peak time of tomato fruit during cold storage (WANG et al., 2008). In this study, the respiration rate of ALAtreated fruit was lower than control fruit throughout storage. ALA induced suppression of respiration in strawberry fruit might be related to the fact that ALA promotes synthesis of the heme prosthetic group of respiration cytochromes.

High ROS levels induced lipid peroxidation, which damages membranes and results in cell senescence. To reduce ROS levels, plants have enzymatic and non-enzymatic defense mechanisms. Antioxidant enzymes such as SOD and APX scavenge

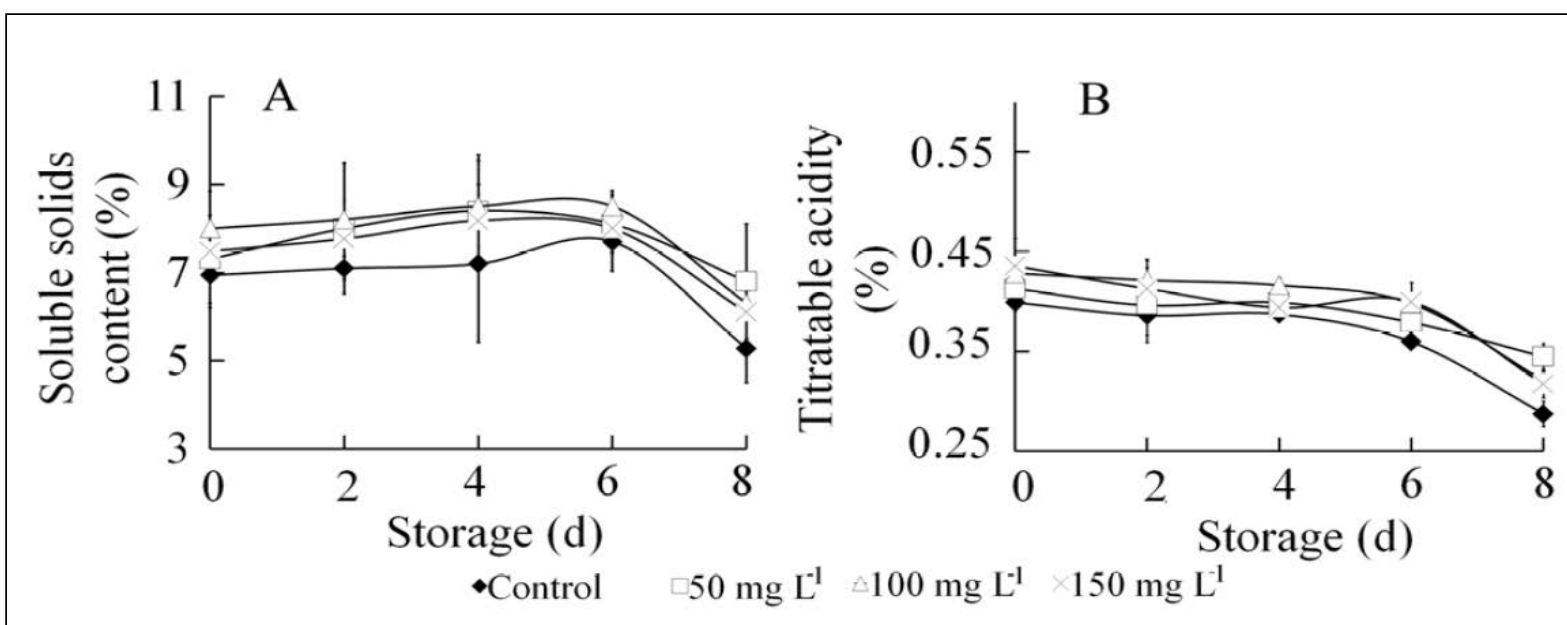

Figure 2 - Analysis of ALA on TSS and TA during storage after harvest at 2, 4, 6, and 8 day in $4 \pm 1^{\circ} \mathrm{C}$. Vertical bars represent $\mathrm{SD}(\mathrm{n}=3$ ). 
ROS and delay senescence (ROGERS, 2012). In our study, fruit treated with ALA had a significantly lower $\mathrm{O}_{2}^{-}$production rate and $\mathrm{H}_{2} \mathrm{O}_{2}$ content compared to control fruit. ALA increased SOD and APX activity throughout storage. These results suggested that there is a close relationship between ALA and antioxidant enzyme activities. The ALA is a precursor of heme, which is a prosthetic group of several antioxidant enzymes. Therefore, ALA might enhance the activities of heme-containing antioxidant enzymes (HOODA et al., 2015).

ALA has been shown to improve apple quality and increase apple soluble sold content (GUO et al., 2013). In our study, pre-harvest applications of ALA improved the qualities of strawberry fruit during storage. Compared to control fruit, ALAtreated fruits had higher TSS and TA than control fruit during storage. Anthocyanins are considered the markers of most fruit ripening. In our study, anthocyanin accumulation of ALA-treated fruits significantly increased compared to the control fruit at initial stage of storage; however, anthocyanin accumulation rapidly increased at the later stage of storage, and the anthoyanin content of the control was significantly higher than ALA-treated fruit. ALA is a precursor in the biosynthesis of phytochromobilin, which is a phytochrome chromophore, ALA may have an effect on the content of phytochromobilin, such that a phytochrome pathway might mediate anthocyanin accumulation in fruit treated with ALA during the initial storage.

\section{CONCLUSION}

In this study, we explored the effects of ALA on the physiological and biochemical characteristics of the 'Sweet Charlie' strawberry fruit. We found that these treatments delayed senescence and improved the qualities of strawberry fruit. Among all treatments, $150 \mathrm{mg} \mathrm{L}^{-1}$ ALA applied at the white stage was the most effective. Our results supported the preharvest application of ALA as a beneficial strategy for preventing postharvest decay of strawberry fruit and extending the shelf life.

\section{REFERENCES}

BEYER, W.F.; FRIDOVICH, I. Assaying for superoxide dismutase activity: some large consequences of minor changes in conditions. Analytical Biochemistry, v.161, p.559-566, 1987. Available from: $<$ http://auth.njau.edu.cn:2050/science?_ob=ArticleListURL\&_ method=list\& ArticleListID $=-870845704 \&$ sort $=r \&$ st $=13 \&$ view $=\mathrm{c} \& \mathrm{md} 5=4991 \mathrm{a} 9 \mathrm{e} 5 \mathrm{fd} 1 \mathrm{fd} 0265559 \mathrm{c} 800 \mathrm{f} 314 \mathrm{e} 4 \mathrm{eb} \&$ searchtype $=\mathrm{a}>$. Accessed: Oct. 15, 2015. doi: 10.1016/0003-2697(87)90489-1.
FU, J.J. et al. Exogenous 5-aminolevulenic acid promotes seed germination in Elymus nutans against oxidative damage induced by cold stress. Plos One, v.9, p.e107152-e107152, 2014. Available from: <https://www.researchgate.net/publication/265517143>. Accessed: Dec. 16, 2015. doi: 10.1371/journal.pone.0107152.

GUO, L.et al. The mechanism analysis of anthocyanin accumulation in peach accelerated by ALA. Acta Horticulturae Sinica, v.6, p.005, 2013. Available from: <http://en.cnki.com.cn/Article_en/ CJFDTOTAL-YYXB201306005.htm>. Accessed: Oct. 15, 2015.

HODGES, D.M. et al. Improving the thiobarbituric acid-reactivesubstances assay for estimating lipid peroxidation in plant tissues containing anthocyanin and other interfering compounds. Planta, v.207, p.604-611, 1999. Available from: <http://link.springer.com/ article/10.1007\%2Fs004250050524>. Accessed: Oct. 15, 2015. doi: $10.1017 / \mathrm{S} 0031182002002585$.

IWAI, $\mathrm{K}$. et al. A new functional fertilizer containing 5-aminolevulinic acid promoted hydroponically-grown vegetables in the Netherlands. International Symposium on Soilless Culture and Hydroponics, v.697, p.351-355, 2005. Available from: $<$ http:// www.actahort.org/books/697/697_44.htm>. Accessed: Dec. 12, 2015. doi: 10.17660/ActaHortic. 2005.697 .44 .

KOSAR, F. et al. Exogenously-applied 5-aminolevulinic acid modulates some key physiological characteristics and antioxidative defense system in spring wheat (Triticum aestivum $\mathrm{L}$.) seedlings under water stress. South African Journal of Botany, v.96, p.71-77, 2015. Available from: <http://ac.els-cdn.com/S0254629914001963/1s 2.0-S $0254629914001963-$ main.pdf? tid=1c686f1e731 b- 11 e 5-bd 15-00000aacb35 \&\&acdnat $=1444899778$ cb802b3c4df3343aa0491e78f239c60e>. Accessed: Oct. 15, 2015. doi: 10.1016/j.sajb.2014.10.015.

LEE, J.Y. et al. Extending shelf-life of minimally processed apples with edible coatings and antibrowning agents. LWT-Food Science and Technology, v.36, p.323-329, 2003. Available from: $<$ http:// www.sciencedirect.com/science/article/pii/S0023643803000148>. Accessed: Dec. 16, 2015. doi: 10.1016/S0023-6438(03)00014-8.

LUKSIENE, Z. et al. New approach to the fungal decontamination of wheat used for wheat sprouts: effects of aminolevulinic acid. International Journal of Food Microbiology, v.116, p.153-158, 2007. Available from: <http://ac.els-cdn.com/S0168160507000761/1s2.0-S0168160507000761-main.pdf? tid=52ef53ae-731b-11e5b5cb-00000aab0f6b\&acdnat $=1444899869 \_835 \mathrm{e} 85 \mathrm{~d} 2 \mathrm{~b} 488 \mathrm{f} 1 \mathrm{~d} 06 \mathrm{~b} 7 \mathrm{~d}$ de15cbf860a8>. Accessed: Oct. 15, 2015. doi: 10.1016/j.

MEMON S.A. et al. Promotive effect of 5-aminolevulinic acid on chlorophyll, ant,ioxidative enzymes and photosynthesis of Pakchoi (Brassica campestris ssp. chinensis var. communis Tsen et Lee). Acta Physiologiae Plantarum, v.31, p.51-57, 2009. Available from: <http://rd.springer.com/article/10.1007/s11738-008-01987>. Accessed: Dec. 16, 2015. doi:10.1007/s11738-008-0198-7.

MEYERS, K.J. et al. Antioxidant and antiproliferative activities of strawberries. Journal of Agricultural and Food Chemistry, v.51, p.6887-6892, 2003. Available from: <http://med.wanfangdata. com.cn/Paper/Detail/PeriodicalPaper_PM14582991>. Accessed: Oct. 15, 2015. doi: 10.1021/jf034506n.

NISHIHARA, E. et al. Role of 5-aminolevulinic acid (ALA) on active oxygen-scavenging system in NaCl-treated spinach (Spinacia oleracea). Journal of Plant Physiology, v.160, p.1085-1091, 2003. Available from: <http://ac.els-cdn.com/S0176161704704976/1-s2.0- 
S0176161704704976-main.pdf?_tid=3a433e78-731c-11e5-80de00000aab0f6b\&acdnat $=1444900257 \_5$ eb9011e430ed6ce369fc201b 1e31eae>. Accessed: Oct. 15, 2015. doi:10.1078/0176-1617-00991.

ROGERS, H.J. Is there an important role for reactive oxygen species and redox regulation during floral senescence? Plant Cell and Environment, v.35, p.217-233, 2012. Available from: $<\mathrm{http} / /$ onlinelibrary.wiley.com/doi/10.1111/j.1365-3040.2011.02373.x/pdf $>$. Accessed: Oct. 15, 2015. doi: 10.1111/j.1365-3040.2011.02373.x.

WANG, T. et al. Effects of 5-aminolevulinic acid on the quality and post harvest physiology of tomato fruit. Journal of Northwest A \& F University (Natural Science Edition), v.36, p.127-131, 2008. Available from: <http://en.cnki.com.cn/Article_en/CJFDTOTALXBNY200810021.htm>. Accessed: Oct. 10, 2015. doi: 10.13207/j.

WANG, S.Y.; JIAO, H. Scavenging capacity of berry crops on superoxide radicals, hydrogen peroxide, hydroxyl radicals, and singlet oxygen. Journal of Agricultural and Food Chemistry, v.48, p.5677-5684, 2000. Available from: <http://pubs.acs.org/toc/ jafcau/48/11>. Accessed: Oct. 15, 2015. doi:10.1021/jf000766i.

WANG, S.Y. et al. Cultural system affects fruit quality and antioxidant capacity in strawberries. Journal of Agricultural and Food Chemistry, v.50, p.6534-6542, 2002. Available from: $<$ http://pubs.acs. org/toc/jafcau/50/22>. Accessed: Oct. 15, 2015. doi:10.1021/jf020614i.

WANG, L.J. et al. Effect of 5-aminolevulinic acid on enhancing apple fruit coloration. Journal of Fruit Science, v.21, p.512-515, 2004. Available from: <http://en.cnki.com.cn/Article_en/CJFDTotal-GSKK200406001. htm>. Accessed: Dec. 16, 2015. doi: 1009-9980(2004)06-512-04.

WANG, Y.; LONG, L.E. Respiration and quality responses of sweet cherry to different atmospheres during cold storage and shipping. Postharvest Biology and Technology, v.92 p.62-69, 2014. Available from: <http:// www.sciencedirect.com/science/article/pii/S0925521414000118>. Accessed: Dec. 16, 2015. doi: 10.1016/j.postharvbio.2014.01.003.

ZHU, L.Q. et al. Effect of a combination of nitric oxide treatment and intermittent warming on prevention of chilling injury of 'Feicheng'peach fruit during storage. Food Chemistry, v.121, p.165-170, 2010. Available from: <http://ac.els-cdn.com/S0308814609014289/1-s2.0S0308814609014289-main.pdf?_tid=d825b20e-732d-11e5-8fac00000aab0f01\&acdnat $=1444907824 \_1$ a608cb03cflad5597caf56e23c 84eac>. Accessed: Oct. 15, 2015. doi: 10.1016/j.foodchem.2009.12.025. 